\title{
Hubungan Pengetahuan, Sikap, Dan Kegiatan Unit Kegiatan Sekolah Dengan Perilaku Merokok
}

\author{
${ }^{1}$ Zamziri*, ${ }^{2}$ Randian \\ ${ }^{1}$ Akademi Keperawatan Pangkalpinang \\ ${ }^{2}$ Dinas Kesehatan Bangka Selatan \\ *email:zim2.faqih11@gmail.com
}

Kata Kunci :

Perilaku

Merokok,

Sikap,

Key Words:

Smoking

Behavior,

Knowledge,

Attitudes, UKS

Activities
Pengetahuan,

Kegiatan UKS

\begin{abstract}
Abstrak
Merokok pada remaja merupakan suatu pemandangan yang sangat tidak asing. Kebiasaan merokok dianggap dapat memberikan kenikmatan bagi perokok sendiri maupun orang disekitarnya. Berbagai kandungan zat yang terdapat di dalam rokok memberikan dampak negatif pada tubuh penghisapnya. Tujuan Penelitian ini untuk mengetahui hubungan antara pengetahuan, sikap, kegiatan UKS dengan perilaku merokok. Penelitian ini merupakan penelitian kuantitatif dengan design Cros sectional. Jumlah sampel sebanyak 49 siswa laki-laki kelas X, XI, XII SMA 1 Toboali menggunakan tekhnik purposive sampling. Hasil analisa data menggunakan uji chi square. Hasil penelitian didapatkan bahwa terdapat hubungan yang signifikan antara pengetahuan, sikap, dan kegiatan UKS dengan perilaku merokok ( $\mathrm{p}$ value $0,025, \& 0,025$ ) sedangkan tidak terdapat hubungan yang signifikan antara kegiatan UKS dengan perilaku merokok dengan $\mathrm{p}$ value 0,098. Bagi tenaga kesehatan disarankan untuk memberikan edukasi kepada remaja SMA tentang dampak merokok sehingga dapat meningkatkan kesadaran remaja untuktidak merokok.
\end{abstract}

Info Artikel:

Tanggal dikirim:

18 Desember

2018

Tanggal direvisi:

12 Januari 2019

Tanggal diterima:

16 April 2019

DOI Artikel:

10.33862/citrad

elima.v3i1.32

Halaman: 1-4

\section{PENDAHULUAN}

Merokok merupakan sesuatu kebiasaan yang lazim tidak asing bagi remaja. Kebiasaan merokok dianggap dapat memberikan kenikmatan bagi perokok sendiri maupun orang disekitarnya. Berbagai kandungan zat yang terdapat di dalam rokok memberikan dampak negatif pada tubuh penghisapnya. Beberapa motivasi yang melatar belakangi merokok adalah untuk mendapat pengakuan (anticipatory beliefs), untuk menghilangkan kekecewaan (reliefing beliefs) dan menganggap perbuatan tersebut tidak melanggar norma (permission beliefs/positive). Hal ini sejalan dengan kegiatan merokok yang dilakukan oleh remaja biasanya dilakukan didepan orang lain, terutama bersama kelompoknya karena mereka sangat tertarik kepada kelompok sebanyanya atau dengan kata lain terikat dengan kolompoknya (Joemana, 2004)

Menurut WHO (1997) menyatakan bahwa perokok sekitar 47\% laki-laki dan 12\% perempuan (WHO, 1997). Menurut Riskesdas (2013) angka kejadian perilaku merokok tahun 2013 sebesar 36,3\%. 64,9 persen laki-laki dan 2,1 persen perempuan masih menghisap rokok tahun 2013. Ditemukan 1,4 persen perokok umur 10-14 tahun, 9,9 persen perokok pada kelompok tidak bekerja, dan 32,3 persen pada kelompok kuintil indeks kepemilikan http://jurnalilmiah.stikescitradelima.ac.id/index.php/JI Vol.3,No.1, Juli 2019

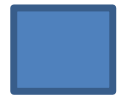


terendah. Sedangkan rerata jumlah batang rokok yang dihisap adalah sekitar 12,3 batang, bervariasi dari yang terendah 10 batang di DI Yogyakarta dan tertinggi di Bangka Belitung (18,3 batang) (Kemenkes, 2013). Proporsi penduduk yang berusia lebih 10 tahun di Provinsi Bangka Belitung tahun 2013 sebesar 26,7\% (Kemenkes, 2013).

Perokok yang hidup saat ini lebih dari satu miliar, 500 juta akan terbunuh oleh tembakau. Kecenderungan saat ini, antara 2005 dan 2030, 175 juta orang bakal terbunuh, berarti lebih dari 8 juta kematian per tahun. Tembakau adalah faktor risiko dalam 6 dari 8 penyebab utama kematian (WHO, 2008). Bahaya merokok bagi kesehatan telah dibicarakan dan diakui secara luas. Para ahli dari WHO menyatakan bahwa di Negara dengan kebiasaan merokok yang telah meluas. Kebiasaan itu mengakibatkan terjadinya $80 \%-90 \%$ kematian akibat kanker paru di seluruh Negara itu, 75\%dari kematian akibat penyakit bronchitis, $40 \%$ kematian akibat kanker kandung kencing dan 25\% kematian penyakit jantung iskemik dan $18 \%$ kematian pada penyakit stroke (Aditama, 2011).

Sekolah adalah sebagai perpanjangan tangan keluarga dalam meletakkan dasar perilaku untuk kehidupan anak selanjutnya, termasuk perilaku kesehatan. Promosi kesehatan atau pendidikan kesehatan di sekolah adalah sangat penting. Di Indonesia, bentuk promosi kesehatan di sekolah adalah Usaha Kesehatan Sekolah (UKS). UKS merupakan salah satu upaya kesehatan masyarakat di sekolah. SMA Negeri 1 Toboali sudah memiliki Program UKS di sekolah. Dalam kehidupan berbangsa, anak sekolah sebagai generasi penerus bangsa. Oleh sebab itu, pendidikan di sekolah adalah merupakan investasi (human investment) bagi pembangunan bangsa (Notoatmodjo, 2010). Penelitian ini bertujuan untuk mengetahui hubungan pengetahuan, sikap, kegiatan UKS dengan perilaku merokok siswa di SMA.

\section{METODE}

Penelitian ini termasuk penelitian kuantitatif, bersifat deskriptif analitik dengan pendekatan cross-sectional. Sampel penelitaan ini adalah 49 siswa yang terdiri dari siswa laki-laki kelas X, kelas XI dan kelas XII SMA Negeri 1 Toboali
Tahun 2011. Pengambilan sampel dilakukan dengan teknik Purposive Sampling.

Analisa pada penelitian ini adalah analisa univariat dan analisa bivariat. Analisis univariat yang dilakukan terhadap tiap variabel dari hasil penelitian, tujuan dari analisis ini hanya untuk menghasilkan distribusi dan persentase dari setiap variabel. Analisa bivariat yang dilakukan terhadap dua variable yang diduga berhubungan atau berkolerasi (Notoatmodjo, 2010). Uji statistik yang digunakan untuk melihat dan membuktikan ada tidaknya hubungan antara variable pengetahuan dan sikap (variable independen) dengan perilaku merokok (variable dependen). Penelitian ini analisis yang digunakan adalah dengan uji kai kuadrat (chi square).

HASIL

Responden berjumlah 49 siswa berpartisipasi dalam penelitian ini.

Tabel 1 Distribusi Frekuensi dan Persentasi Pengetahuan, Sikap, Kegiatan UKS dan Prilaku Merokok di SMA Negeri 1 Toboali $(n=49)$

\begin{tabular}{lcc}
\hline \multicolumn{1}{c}{ Variabel } & Jumlah & Presentasi \\
\hline Pengetahuan & & \\
Baik & 46 & 93.9 \\
Buruk & 3 & 6.1 \\
Sikap & & \\
Aktif & 46 & 93.9 \\
Tidak Aktif & 3 & 6.1 \\
Kegiatan UKS & & \\
Ada & 29 & 59.2 \\
Tidak Ada & 20 & 40.8 \\
$\begin{array}{l}\text { Perilaku } \\
\text { Tidak Merokok }\end{array}$ & 34 & 69.4 \\
Merokok & 15 & 30.6 \\
\hline
\end{tabular}

Berdasarkan tabel 1 Pengetahuan dari 49 Responden terdapat 46 orang siswa (93.9\%) mempunyai pengetahuan dengan katagori baik. Sikap dari 49 Responden terdapat 46 orang siswa (93.9\%) mempunyai sikap dengan katagori positif. Kegitan UKS dari 49 Responden terdapat 29 orang siswa (59.2\%) mengatakan ada kegiatan UKS di Sekolah. Perilaku dari 49 Responden terdapat 34 orang siswa (69.4\%) tidak merokok, dan terdapat 15 orang siswa $(30.6 \%)$ merokok. 
Tabel 2 Hubungan Pengetahuan, Sikap, Kegiatan UKS dan Prilaku Merokok di SMA Negeri 1 Toboali $(n=49)$

\begin{tabular}{lc}
\hline \multicolumn{1}{c}{ Variabel } & $P$ value \\
\hline Pengetahuan & 0,025 \\
Sikap & 0,025 \\
Kegiatan UKS & 0,098 \\
\hline
\end{tabular}

Berdasarkan tabel 1 bahwa ada hubungan antara pengetahuan, sikap dengan prilaku merokok siswa. Bahwa tidak ada hubungan antara kegiatan UKS dengan prilaku merokok siswa.

\section{PEMBAHASAN}

Hasil penelitian didapatkan ada hubungan yang signifikan antara pengetahuan dengan perilaku merokok siswa di SMA Negeri 1 Toboali Kabupaten Bangka Selatan Provinsi Kepulauan Bangka Belitung.

Menurut Notoatmodjo (2005). Pengetahuan (knowledge)merupakan hasil pengeinderaan manusia atau hasil dari tahu seseorang terhadap objek melalui indera yang dimilikinya. Dengan kata lain penginderaan seseorang terhadap objek mempunyai intensitas atau tingkat yang berbedabeda.

Pengetahuan juga merupakan sesuatu yang hadir dan terwujud dalam jiwa dan pikiran seseorang dikarenakan adanya reaksi, sentuhan, hubungan dengan lingkungan dan alam sekitar (Isyraq, 2007)

Menurut Notoatmodjo (2007) Pengukuran pengetahuan dapat dilakukan dengan wawancara atau kuesioner yang menanyakan tentang isi materi yang ingin diukur dari subjek penelitian atau responden. Kedalaman pengetahuan yang ingin kita ketahui atau kita ukur dapat kita sesuaikan dengan tingkatan-tingkatan diatas. Pengetahuan responden tentang seputar konsep rokok diperoleh dengan mengajukan 10 pertanyaanyang harus dijawab benar semua oleh siswa berisi tentang pengertian rokok, zat-zat yang terkandung dalam rokok, bahaya merokok dan penyakit yang dapat ditimbulkan oleh rokok.Banyaknya siswa memahami pengetahuan tentang perilaku merokok membuktikan bahwa sumber informasi tentang perilaku merokok telah sampai kepada siswa SMA.

Hasil penelitian didapatkan bahwa ada hubungan yang signifikan antara sikap dengan perilaku merokok. Sikap merupakan respons tertutup seseorang terhadap stimulus atau objek tertentu, yang sudah melibatkan faktor pendapat dan emosi yang bersangkutan. Newcomb salah seorang ahli psikologi sosial, menyatakan bahwa sikap itu merupakan kesiapan atau kesediaan untuk bertindak, dan bukan merupakan pelaksanaan motif tertentu. Sikap belum merupakan suatu tindakan atau perilaku, akan tetapi merupakan predisposisi tindakan suatu perilaku (Noetoatmodjo, 2005)

Sikap positif yang sebagian besar dimiliki oleh siswa kemungkinan besarsudah ditanamkan nilai moral dan sosial dari orang tua dan sekolah.

Hasil analisis didapatkan terdapat hubungan yang signifikan antara kegiatan UKS dengan perilaku merokok. Di Indonesia, bentuk promosi kesehatan di sekolah adalah Usaha Kesehatan Sekolah (UKS), dan sekaligus UKS merupakan salah satu upaya kesehatan masyarakat di sekolah. Komunitas sekolah yang terdiri dari murid, guru dan karyawan sekolah, baik ditingkat sekolah dasar (SD), sekolah lanjutan pertama (SLP), dan sekolah lanjutan atas (SLA) adalah merupakan sasaran dari promosi kesehatan di sekolah. Dalam kehidupan bangsa, anak sekolah tidak dapat di abaikan, karena mereka inilah sebagai generasi penerus bangsa. Oleh sebab itu, pendidikan di sekolah adalah merupakan investasi (human investment) bagi pembangunan bangsa. (Notoatmodjo, 2010)

Promosi kesehatan di sekolah merupakan suatu upaya untuk menciptakan sekolah menjadi suatu komunitas yang mampu meningkatkan derajat kesehatan masyarakat sekolah melalui 3 kegiatan utama (a) penciptaan lingkungan sekolah yang sehat,

(b) pemeliharaan dan pelayanan di sekolah, dan (c) upaya pendidikan yang berkesinambungan. Ketiga kegiatan tersebut dikenal dengan istilah TRIAS UKS. 
Anak sekolah merupakan kelompok yang sangat peka untuk menerima perubahan atau pembaruan, karena kelompok anak sekolah sedang berada dalam taraf pertumbuhan dan perkembangan (Notoatmodjo, 2010)

\section{SIMPULAN}

Adanya hubungan yang bermakna antara pengetahuan dengan perilaku merokok siswa, sikap dengan perilaku merokok siswa dan tidak terdapat hubungan yang bermakna antara Kegiatan UKS dengan perilaku merokok siswa.

\section{DAFTAR PUSTAKA}

Aditama, T. Y. 2011. Rokok dan Kesehatan. Jakarta: UI-Press.

Arneti. 2002. Pengetahuan sikap dan Persepsi Siswi SD kelas IV, V dan VI tentang Menstruasi di SD Air Pacah (Pedesaan) dan di SD Nanggalo Siteba(perkotaan). Skripsi, Program Studi Kesehatan Masyarakat : Universitas Indonesia.

Becker, J. 2008. Tip Cerdas Agar Anak Anda Berhenti Merokok. Jakarta: Prestasi Pustakaraya.

Bangun, A.P. 2003 Panduan Untuk Perokok: Sulusi Tuntas Untuk Mengurangi Rokok dan Berhenti Merokok. Jakarta: Milenia Populer..

Brigham, C.J.1991Social Psychology. Boston: Harper Collins Publisher, Inc.

Crofton, J \& Simpson, D. 2009. Tembakau: Ancaman Global. Jakarta: PT Gramedia.

Danusantoso. H.1991 Rokok dan Perokok. Jakarta: Arcan.

Departemen Kesehatan, RI

2008. Promosi kesehatan di sekolah. Jakarta: Dinkes
Indonesia, Media.2008. Perokok Pemula di Indonesia Meningkat. Dapat diakses pada Indeks Koran Buku II Media Indonesia hal 29 Perpustakaan UI. Tanggal 16 Juli 2011.

Kartono, M.1998Kontradiksi dalam Kesehatan Reproduksi. Jakarta: Pustaka Sinar Harapan.

Kementerian Kesehatan RI, Badan Litbangkes

2013. Riset Kesehatan Dasar (Riskesdas) 2013. Jakarta: Kementerian Kesehatan RI.

Notoatmodjo, S. 2007. Promosi kesehatan dan Ilmu Perilaku. Jakarta: PT Rineka Cipta.

Notoatmodjo. 2010. Metodologi Penelitian Kesehatan. Jakarta: PT Rineka Cipta.

Supranto, J. 2000. Teori dan Aplikasi (edisi revisi ke 6) jilid 1. Jakarta

Sitepoe, M. 2000. Kekhususan Rokok Indonesia mempermasalahkan PP No. 81 Tahun 1999 tentang Pengamanan Rokok bagi Kesehatan. Jakarta: PT Grasindo. 